\title{
Batee Iliek Tourism Development Model
}

\author{
By: \\ Nazaruddin ${ }^{1},{ }^{*}$ Ahmad Yani², Ti Aisyah4 ${ }^{4}$ Yulia Rahmi ${ }^{5}$ \\ 1,Public Administration Departement, Faculty of Sosial and Political Sciences, Universitas \\ Malikussaleh, Lhokseumawe, Indonesia \\ Email : nazaruddin@unimal.ac.id
}

\begin{abstract}
Batee Iliek Tourism Object Development Model in Bireuen Regency which is nature tourism for the welfare of the community by developing objects or attractions, accessibility, amenities, supporting facilities, and institutions through government policies. The aim is to increase income and better economic development and provide job opportunities for the Batee Iliek community in Bireuen Regency and increase national income. The methodology used in this study uses a qualitative methodology and this study aims to obtain an overview of the Batee Iliek Tourism Object Development Model in Bireuen Regency. The results showed that the government and the community played a role in the tourism development program in Batee Iliek through the development of facilities, the development of tourist attractions, increasing the security of village tourist attractions and the development of cultural diversity in the area. The solutions given by the government are to provide facilities such as parking lots, bathrooms, and prayer rooms. By creating a diversity or regional characteristic, such as introducing Acehnese culture. introducing Acehnese cuisine, and selling unique bags with Acehnese carvings can attract visitors.
\end{abstract}

keywords: Model, development, Tourism,, Batee Iliek

\section{Introduction}

The development of tourism destinations must at least include the following main components, namely: 1) Objects and attractions which include: attractions that are usually based primarily on natural, cultural, or artificial wealth, such as events or what are often called special interests. ; 2) Accessibility which includes transportation system support which includes: other transportation routes or routes; 3) Amenities which include supporting and supporting tourism facilities which include: accommodation, restaurants, retail, souvenir shops, money exchange facilities, travel buses, tourist information centers, and other convenience facilities; 4)
Supporting facilities (Ancillary Services), namely the availability of supporting facilities used by tourists, such as banks, telecommunications, postal services, hospitals, and so on; 5) Institutions, which are related to the existence and role of each element in supporting the implementation of tourism activities, including the local community as the host. Cooper, Fletcher, Gliberth, Shepherd dan Wanhill (1998).

Batee Iliek tourism is already wellknown among the public, both within the region and outside the region. This place has been a famous tourist attraction since the early 90's. Since early 2007, the tourist attraction area of Batee Iliek has been beautified by setting up cottages that are 
neatly lined along the riverbank, making it easy for visitors to enjoy the panoramic beauty of Batee Iliek baths.Batee Iliek tourism is already well-known among the public, both within the region and outside the region. This place has been a famous tourist attraction since the early 90's. Since early 2007, the tourist attraction area of Batee Iliek has been beautified by setting up cottages that are neatly lined along the riverbank, making it easy for visitors to enjoy the panoramic beauty of Batee Iliek baths.

From year to year the number of tourist visitors to Batee Iliek has fluctuated as shown in the table below:

Graph of the number of visitors from tourists at the Batee Iliek Tourism Object from 20172019:

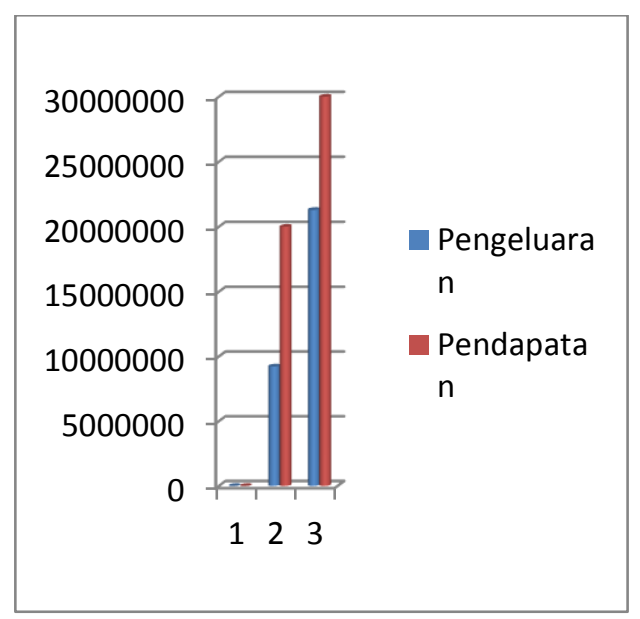

Source: District Office Samalanga2020

Based on the data, it can be seen that the number of tourist visitors in 20182019 has increased so as to provide an increase also in the income of the tourism sector to Batee Iliek in Samalanga District, but in the following year there was a decrease due to the reduced number of visits compared to the previous year.
With the existence of the Batee Iliek tourist attraction, people can run small businesses, so that people get income for family needs. The high and low income of the community or income for the Batee Iliek tourism cash itself is caused by visitors at the Batee Iliek tourist spot.

Based on the data that the researchers got, Batee Iliek tourism is in the form of a prayer room with good conditions, where the facilities in the prayer room are equipped with mukena. In tourist areas where every visitor has to maintain cleanliness, but at the Batee Iliek tourist attractions there are no garbage disposal facilities so that the cleanliness conditions along the road to the location there is a lot of scattered garbage which is very disturbing to the beauty of the Batee Iliek tourist attraction, because of the facilities existing facilities cannot accommodate users properly, and coupled with a parking system that has not been properly managed and a Toilet Washing Toilet (MCK) that meets the standards, thus making visitors feel uncomfortable to clean their bodies and change clothes, and so that visitors can enjoy Batee Iliek's recreation with fun.

From the description above, the researcher is interested in further research related to Batee Iliek tourism with the title "The Batee Iliek Tourism Development Model in Bireuen Regency".

\section{Research Problem}

Based on the description of the background above, the researcher formulates the problem with the question: How is the Batee Iliek tourism development model in 
Bireuen Regency, which is focused on attractiveness, accessibility, facilities, and institutions.

\section{Tourism Development}

Tourism is a trip that is carried out for a while, which is organized from one place to another, with the intention not to try or earn a living in the place visited but solely to enjoy the journey of life for sightseeing and recreation or fulfilling various desires. (Yoeti 1996:108). Robert Mc.Intosh together Shashiakant Gupta stated that tourism is the combination of phenomena and relationships arising from the interaction of tourists, businesses, host governments and host communities in the process of attracting and serving these tourists and other visitors. (Pendit, 1999:31).

Tourism is an inseparable part of human life, especially regarding social and economic activities. Starting from activities that were previously only enjoyed by a relatively wealthy few people at the beginning of the 20th century, now they have become part of human rights. This is happening not only in developed countries but also in developing countries. Indonesia as a developing country in its development stage, is trying to build the tourism industry as one way to achieve a balanced foreign trade balance. Through this industry, it is hoped that foreign exchange income can increase (Pendit, 2002).

\section{Theory of Model Tourism}

The development of tourism destinations must at least include the following main components, namely: 1) Objects and attractions which include: attractions that are usually based primarily on natural, cultural, or artificial wealth, such as events or what are often called special interests. ; 2) Accessibility which includes transportation system support which includes: other transportation routes or routes; 3) Amenities which include supporting and supporting tourism facilities which include: accommodation, restaurants, retail, souvenir shops, money exchange facilities, travel buses, tourist information centers, and other convenience facilities; 4) Supporting facilities (Ancillary Services), namely the availability of supporting facilities used by tourists, such as banks, telecommunications, postal services, hospitals, and so on; 5) Institutions, which are related to the existence and role of each element in supporting the implementation of tourism activities, including the local community as the host. Cooper, Fletcher, Gliberth, Shepherd dan Wanhill (1998).

\section{Research Methods/Method of Research}

The method is used to deepen this research is descriptive with quantitative analysis, to achieve the general description of the Tourism Development Model

Regional Government in Batee Iliek

\section{Discussion}

\section{A. Batee Iliek Tourism Development Model in Bireuen Regency in Increasing Community Income}

Tourism development aims to provide benefits for tourism which is expected to be able to improve the standard of living of the community through the economic benefits it 
brings to the area. In other words, tourism development through the provision of infrastructure facilities, tourists and local residents will benefit from each other. Such development should pay close attention to various aspects, such as: cultural, historical and economic aspects of tourist destinations. In Batee Iilek, it is necessary to develop further by developing all touristdestinations, including the Teungku Chik house in Awe Geutah in Awe Geutah Village, Kecamatan Peusangan Siblah Krueng, Meuligo the Regent of Bireuen in downtown Bireuen, the grave of Syuhada Lapan in Cot Batee Geulungku, Simpang Mamplam district, Cot Panglima in Juli sub-district, Krueng Simpo in Krueng Simpo village, Juli district, Batee Iliek in Samalanga district, and Ujong Blang beach in the village Ujong Blang Kuala District, Kuala Jangka Beach is located east of Bireuen City, Peuneulet Baroh Beach in Simpang Mamplam District.

By developing amenities. Amenity/facility is a very necessary means to expedite the implementation of functions and facilities. The function and convenience in question are of course the functions and conveniences attached to the scope of the existence of a facility. In general, a facility is divided into categories, namely social facilities, namely facilities provided by the government or the private sector for the community, such as schools, clinics, shelter houses, places of worship, etc. public facilities, such as roads, bridges, city parks, public lighting devices, and others of the like. So far, the government has provided facilities such as electricity networks, Pertamina, bathrooms, toilets, prayer rooms, and parking lots. From the location of the Batee Iliek Tourism, there are also health centers, and Pertamina.

\section{Tourist Attraction in Tourism Development Model}

Generally, the attractiveness of a tourist attraction is based on the presence of resources that can create a sense of pleasure, beauty, comfort and cleanliness, high accessibility to be able to visit it, the existence of special characteristics / specifications that are rare, the existence of supporting facilities and infrastructure to serve tourists who want to visit it. present, natural attractions have an attraction because of the beauty of nature, mountains, rivers, beaches, sand, forests and so on. All tourist destinations in Bireun have their own charm, one of which is Batee Iliek tourism which has a natural tourism in the form of a river with large rocks along the river.

\section{Accessibility of Tourism Development Model}

Accessibility (or accessibility, achievability) is the degree of ease achieved by people, to an object, service or environment. In another sense, accessibility is a measure of the ease with which a location can be reached from other locations through the transportation system.

Measures of affordability or accessibility include the ease of time, cost, and effort in moving between places or regions. Ease of access is implemented in buildings, the environment and other public facilities that are not yet adequate. 
3. Amenity or Facilities and Institutional Support in Tourism Development Model

The development of tourism infrastructure that considers the conditions and location will increase the accessibility of a tourist attraction which in turn will be able to increase the attractiveness of the tourist attraction itself. In addition to the various needs mentioned above, the needs of other tourists also need to be provided in tourist destinations such as banks, pharmacies, hospitals, gas stations, shopping centers and so on that have not been met at the Bate Iliek tourist spot.

In carrying out the development of tourism infrastructure, there is a great deal of coordination between the relevant agencies along with tourism installations at various levels. The support of relevant agencies in building tourism infrastructure is indispensable for the development of tourism in the region. Coordination at the planning level followed by coordination at the implementation level is the main capital for the success of tourism development, but this is working as it should in Batee Iliek tourism..

\section{Conclusion}

The development of advanced tourism will produce various effects that benefit regional incomes and local communities. Good tourism development will create various effects, one of which is the advancement of tourism such as Batee Iliek in Bireun Regency.

The development efforts that have been carried out are that the surrounding community has made various efforts such as increasing attractiveness, cleaning the Batee Iliek river, painting the stalls to make them look unique and arranging them to look neat, the managers have also promoted these tourist attractions on the internet, through the official website. Batee Iliek village and Batee Iliek tourism facebook specially created to share the natural beauty of Batee Iliek tourism. Also in terms of amenities/supporting facilities, although they are still inadequate, these supporting facilities can be complementary in these tourist attractions such as electricity networks, Pertamina, toilets, toilets, prayer rooms, and parking lots.

\section{References}

Cooper,C.,J.Fletcher,D.Gilbert,A.FyalldanS. Wanhill(1998).Tourism:Principle and Parctice, R. Shepherd, Penyunt., Harlow: Longman.PenerbitUniversitasIndonesi a

Paturusi,Samsul.(2001).PerencanaanTataRuan gKawasanPariwisata(KajianPariwisataPr ogramPascasarjana).Denpasar:Universi tasUdayana

Poerwadarminta(2002).KonsepPengembangan Wisata.BinaRupaAksara.

Jakarta.

Moleong,LexyJ.(2007). MetodologiPenelitianKualitatif.Penerbit PTRemajaRosda KaryaOffset,Bandung.

Paturusi, Samsul A. (2001). Perencanaan Tata Ruang Kawasan Pariwisata, ProgramPasca SarjanaUniversitasUdayanaDenpasar, Bali.

Gibson,Ivancevich,Donelly.(1996).Organisasi, Perilaku,Struktur,Proses.BinaRupa Aksara. Jakarta. 
Suwantoro,Gamal.1997.Dasar-

DasarPariwisata.Andi.Yogyakarta.

Undang-Undang

RepublikIndonesiaNomor10Tahun2 009

Tentang
Kepariwisataan.Jakarta,MenteiKebuda yaandanPariwisata.

QanunNomor8Tahun2013TentangKepawisata an 